\title{
Pomoc Jointu i Agro-Jointu dla ludności żydowskiej na obszarze Białorusi radzieckiej
}

Zarys treści: Powstałe po 1917 r. państwo radzieckie stało się spadkobiercą imperium carskiego, którego przestrzeń geopolityczną bolszewicy zamierzali utrzymać. Zespolić tak, by poszczególne społeczności przyjęły jeden, wspólny, radziecki system wartości, norm i ocen. Fragmentem integracyjnej polityki narodowościowej była rolnicza akcja osiedleńcza ludności żydowskiej. Postanowiona przez Komitet Centralny RKP w 1924 r. akcja kolonizacyjna miała sprzyjać uformowaniu się w tej społeczności warstwy chłopskiej, a więc transformacji jej kultury w kierunku zespolenia $\mathrm{z}$ wielonarodowym społeczeństwem radzieckim. W związku z brakiem państwowych środków pieniężnych, wykonanie odgórnie ustalonych planów stało się możliwe dzięki pomocy finansowej pochodzącej z zewnątrz, zwłaszcza od amerykańskiej organizacji Agro-Joint.

Outline of content: The Soviet state that emerged after 1917 became the heir of the Russian Empire and its geopolitical situation, which the Bolsheviks intended to preserve and consolidate in order for different communities to adopt one common Soviet system of values, norms and opinions. The resettlement of the Jewish community into rural areas was one of the aspects of the ethnic integration policies. The operation, launched by the Central Committee of the RCP(b) in 1924, aimed to facilitate the formation of a peasant stratum in the Jewish society, which would transform its culture in a way to merge the Jews with the multinational population of the USSR. Considering the lack of state funds, the implementation of the top-down plan was made possible by financial aid from external sources, the American organisation Agro-Joint in particular.

Słowa kluczowe: Joint, Agro-Joint, ZSRR, kolonizacja, osadnicy żydowscy w ZSRR

Keywords: Joint, Agro-Joint, Jews in the USSR, Jewish colonization, Jewish settlers in the USRR 
13 stycznia 1953 r. agencja TASS ${ }^{1}$ opublikowała notatkę zatytułowaną „Aresztowanie zbrodniczej grupy lekarzy". Donosiła ona, że organa bezpieczeństwa zdemaskowały lekarzy, którzy postawili sobie za cel uśmiercenie przedstawicieli najwyższych władz państwowych. Mieli oni tego dokonać przez stawianie błędnych diagnoz i celowe, nieprawidłowe leczenie. Spośród dziesięciu zatrzymanych medyków, sześciu było narodowości żydowskiej.

Oskarżenie opierało się na twierdzeniu, że większość grupy terrorystycznej była związana $\mathrm{z}$ międzynarodową, żydowską, burżuazyjno-nacjonalistyczną organizacją Joint ${ }^{2}$. Według informacji, została ona utworzona przez wywiad amerykański i ukryta pod szyldem amerykańskiej pomocy dla Żydów żyjących w diasporze, w tym w Związku Radzieckim. W toku śledztwa ustalono, że organizacja ta prowadziła wrogą działalność nacjonalistyczną i szpiegowską. Większość aresztowanych zeznała, że otrzymywała wskazówki stopniowego wyniszczenia kadr rządzących ZSRR od jej przedstawicieli. Pozostali okazali się agentami wywiadu angielskiego. Skutecznie przeprowadzona kampania propagandowa sprawiła, że przez dziesięciolecia przedstawiano Joint w negatywnym świetle lub po prostu milczano o jego zasługach w niesieniu pomocy narodom Rosji i później Związku Radzieckiego. W rzeczywistości jednak działalność tej organizacji należy postrzegać przez pryzmat humanitarny i historyczny.

W 1921 r. Rosja radziecka przeżywała wielki kryzys polityczny i ekonomiczny. Jego straszliwym wyrazem był głód lat 1921-1922. Objął on swym zasięgiem urodzajne ziemie Rosji i Ukrainy. Według publikowanych danych, głodowało wówczas około 13 milionów osób ${ }^{3}$. Do tej liczby należy jednak dodać dziesiątki milionów

1 TASS - Tielegrafnoje Agientstvo Sovietskogo Sojuza - centralna agencja prasowa ZSRR, założona w lipcu 1925 r., następczyni Rosyjskiej Agencji Telegraficznej.

2 American Jewish Joint Distribution Committee, JDC, zwany też w skrócie Joint (Amerykańsko-Żydowski Połaczony Komitet Rozdzielczy) - organizacja non-profit założona w USA 27 XI 1914 r. z inicjatywy bankiera i filantropa Feliksa Warburga oraz działaczy społecznych: Lui Marszala i Dżordża Sziffa. Powstała w wyniku połączenia trzech organizacji: Amerykańskiego Żydowskiego Komitetu Pomocy, Centralnego Komitetu Pomocy i Narodowego Komitetu Pomocy. Jej fundusze pochodziły głównie z datków amerykańskich Żydów. Od początku założenia skupiała się na wspieraniu prywatnego lub publicznego dobra, nie kierując się osiągnięciem zysku. Celem działania organizacji była pomoc Żydom, głównie w Europie środkowej i wschodniej oraz w Turcji. Na skutek pogromów i wojen mieszkający tu Żydzi utracili domy i możliwości egzystencji. W sumie przez pierwsze pięć lat działalności wydatkowała 38 mln dolarów. Kiedy w 1915 r. w Rosji został złożony „Żydowski Komitet Pomocy Ofiarom Wojny” (Evrejskij Komitet Pomoszczi Żertvam vojny - EKOPO), Joint czynnie włączył się w pomoc niesioną przez tę organizację. O jego zaangażowaniu najlepiej świadczy kwota 240 tys. (na ogólnie wydatkowaną sumę 350 tys.) dla żydowskich uciekinierów i rodzin wysiedlonych ze strefy działań wojennych.

3 Kwestia głodu nie jest tematem artykułu, lecz tylko wstępem kreślącym pierwsze lata działalności Jointu na terenie Związku Radzieckiego. Tytułem uzupełnienia nadmieniam, iż literatura przedmiotu jest bardzo obszerna, począwszy od pierwszych opracowań po współczesne np.: M. B. Gurevicz, Gołod i selskoe chozjajstvo Ukrainy, Charkov 1923; H. Fisher, The Famine in Soviet Russia: 1921-1923. The Operations of the American Relief Administration, New York, Macmilan, 1927; R. Serbin, Gołod 1921-1923 i ukrainska presa v Kanadi, Toronto 1992. 
chłopów z obszarów oficjalnie nieobjętych klęską nieurodzaju oraz głodujących mieszkańców miast leżących w gruzach w wyniku działań wojennych. Głód obejmujący wielkie obszary państwa radzieckiego był wynikiem wielu przyczyn m.in.: wojny, wojenno-komunistycznych metod zarządzania gospodarką, prześladowań indywidualnej gospodarki chłopskiej oraz klęski chudych lat 1920-1921. Śmierć głodowa grożąca dziesiątkom milionów ludzi stanowiła zagrożenie dla istniejącego nowego ustroju społecznego. Rozmiary kryzysu były tak ogromne, iż wiadomo było, że kraj o własnych siłach nie jest w stanie ich przezwyciężyć. W tym momencie za fenomen w skali historycznej można uznać pomoc okazaną państwu radzieckiemu przez przeciwników politycznych - kraje zachodu. Niemal cały świat zjednoczył się w szeroko zakrojonej akcji pomocy głodującym narodom Rosji. Przez półtora roku wwieziono około 50 mln pudów ${ }^{4}$ żywności, lekarstw i odzieży. Ludzkie odruchy miłosierdzia wzięły górę nad konfrontacją polityczną, ideologiczną.

Postrzegając działalność Jointu przez pryzmat humanitaryzmu, zadziwiające wydają się ataki władz radzieckich na tą organizację. Poza zarzutami odnoszącymi się do bezpieczeństwa państwowego wiele oskarżeń dotyczyło „nagannego sposobu rozprowadzania darów, skandalicznego doboru osób w komisjach oraz kierowania się w działalności dobroczynnej wykładnią nacjonalistyczną". Chcąc, choć zwięźle, przybliżyć ten problem, należy odnotować, iż ofiarodawcami Jointu była ludność żydowska Stanów Zjednoczonych. Darczyńcy w większości wypadków mieli życzenie, aby ich pomoc trafiła do określonych grup społecznych zamieszkujących wskazane miasteczka lub była przeznaczona na potrzeby uczącej się młodzieży, ofiar pogromów, zwłaszcza dla sierot. Organizacja zobowiązana była wypełnić ich wolę. Ponadto ona sama, zgodnie ze statutem, została utworzona w celu niesienia pomocy ludności żydowskiej byłego imperium rosyjskiego. Jednakże myliłby się ten, kto twierdziłby, iż Joint był organizacją ograniczającą swoje działania tylko do tej narodowości. Analiza dokumentów pokazuje, że priorytetem jej działalności było szeroko pojęte niesienie pomocy.

Z 1,3 mln dol. wydanych na pomoc żywnościową w 1923 r., 250 tys. spożytkowano na osadnictwo rolne ludności żydowskiej mieszkającej w miastach i miasteczkach. Z tego około $40 \%$ środków przeznaczonych na nasiona, maszyny i żywy inwentarz, wydano dla ludności niemającej żydowskich korzeni. Ten procent odnosi się również do pomocy dzieciom i innych form walki z głodem. Ponadto Joint znaczną część swoich środków kierował na Powołże, gdzie nie było koncentracji społeczności żydowskiej. Jego pomoc rozciągała się na Tatarstan, Dagestan i głodujące rejony Kirgizji (Kazachstanu) .

4 Pud - dawna rosyjska jednostka masy, używana też często w czasach radzieckich, odpowiadająca $16,38 \mathrm{~kg}$.

5 Nie sposób w krótkiej formie artykułu szerzej omówić wszystkich wątków związanych z obszernym tematem pomocy ludności żydowskiej w Związku Radzieckim. W dalszej jego części niektóre instytucje czy osoby szczególnie zaangażowane w akcję osadnictwa ludności żydowskiej na roli pozostają wymienione tylko z nazwy lub nazwiska. Pomija się cele, charakter i przedstawienie ich działalności. Bazę źródłową artykułu stanowią przede wszystkim dokumenty z archiwów Moskwy oraz Mińska. Należy je traktować 
Narodowy charakter, w znacznej części, nosiła jedynie funkcja Jointu, a wcześniej również ARA ${ }^{6}$, związana z rozprowadzaniem przesyłek. Paczki spożywcze i odzieżowe były opłacane za granicą przez nadawcę (osobę fizyczną lub grupę społeczną). W magazynach Jointu były przygotowane artykuły spożywcze i odzież, które wydawano za okazaniem dokumentu opłaty. W ten sposób wskazany adresat otrzymywał opłaconą paczkę. Z dziesiątków tysięcy paczek rozprowadzonych do końca listopada 1922r.: 130,5 tys. trafiło do Odessy, 95,2 tys. do Kijowa, 58,8 tys. do Ekaterinosławia, 36 tys. do Mińska, 84,3 do Moskwy, 56,7 tys. do Piotrogradu. Głodująca gubernia samarska otrzymała tylko 8,2 tys. paczek, Baszkiria 5,4 tys. ${ }^{7}$ $\mathrm{Z}$ doręczonych przesyłek w miastach Białorusi ponad połowa trafiła do ludności żydowskiej, do której były imiennie zaadresowane. Nadawali je członkowie rodzin, przyjaciele, sąsiedzi, którzy wyemigrowali z Rosji do USA. Trzeba zaznaczyć, że często sami nadawcy zobowiązywali do doręczenia przesyłek rabinów, których znali osobiście i ufali ich prawości. Skarg kierowanych przez miejscowych funkcjonariuszy do władz wyższych, iż rabini rozprowadzają pomoc zagraniczną, było wiele. Nie ma w nich jednak konkretnych zarzutów wskazujących na niesprawiedliwy podział. W zgłoszeniu z Mińska np. zarzucano, że pomoc otrzymali członkowie społeczności religijnej „Talmud Tora”. Przynależność do organizacji religijnej nie oznaczała jednak, że jej członkowie nie potrzebowali takiej pomocy. Uczący się w jesziwach często znajdowali się bowiem w trudniejszych warunkach bytowych niż rzemieśl-

jako podstawowe. Zespoły znajdujące się w innych krajach, np. w Stanach Zjednoczonych, oparte głównie na wspomnieniach oraz kopiach dokumentów znajdujących się na Wschodzie, nie wnoszą nowych treści do tematu, a jedynie mogą wzbogacić o drobne szczegóły. Uwzględnione w artykule sprawozdania organów radzieckich, choć „zrytualizowane”, w których wiele spraw pomijano czy przeinaczano, z racji przedstawienia ówczesnej sytuacji należy uznać za oddające swoisty klimat czasu. Mimo że zawierają jednostronne informacje, nie oznacza to, iż przyjmowane są bezkrytycznie. Cytowane fragmenty opatrzone są, na końcu poruszanych zagadnień, stosownym komentarzem.

6 Pisząc o pierwszych latach działalności Jointu w ZSRR, należy dodać, iż początkowy okres jego aktywności był ściśle związany z działalnością American Relief Administration (dalej: ARA). Amerykańska Administracja Pomocy już w sierpniu 1921 r., jako pierwsza organizacja amerykańska, otrzymała od władz państwa radzieckiego prawo samodzielnego rozprowadzania wwożonej pomocy i jednocześnie została zobowiązana do natychmiastowego zorganizowania karmienia głodujących dzieci Powołża. ARA została powołana przez amerykański Kongres 24 lutego 1919 r. jako organizacja rządowa mająca na celu dostarczenie, po zakończeniu I wojny światowej, pomocy humanitarnej do Europy (później także ZSRR). Początkowo dysponowała budżetem $100 \mathrm{mln}$ USD. Suma ta rychło wzrosła dzięki napływowi środków prywatnych, m.in. dzięki wkładowi Jointu. ARA dostarczyła ok. 4 milionów ton artykułów do 23 krajów (przede wszystkim Wielkiej Brytanii, Francji, Włoch, Belgii, Czechosłowacji, Niemiec, Austrii, Polski i ZSRR, a także krajów bałtyckich, Armenii, Jugosławii, Węgier, Rumunii i Turcji). American Relief Administration zakończyła działalność w Europie w czerwcu 1922 r. Całkowity koszt pomocy wyniósł 200 milionów dolarów.

$7 \mathrm{Na}$ Powołżu największa liczba paczek trafiła do guberni saratowskiej, gdzie była koncentracja ludności niemieckiej. Centralnyj Gosudarstviennyj Archiv Oktiabr’skoj Riewolucyi, vysszych organov gosydarstviennoj vłasti i organov gosydarstviennogo upravlenija SSSR (dalej: CGAOR); CGAOR, f. 1062, op. 3, d. 17, 1. 17.

8 Ibidem, f. 1058, op. 1, d. 303, 1l. 1, 2, 6. 
nicy i robotnicy. Wyjaśnienia konfliktów na tej płaszczyźnie kładły się cieniem na stosunkach między władzami radzieckimi a kierownictwem ARA i Jointu.

Dzięki zaangażowaniu Jointu skala żywnościowej pomocy amerykańskiej szybko rosła. Na początku wiosny w stołówkach ARA wydawano posiłki dla 2-3 mln dzieci. Już jesienią 1921 r. Joint wyasygnował na konto organizacji kwakrów ${ }^{9}$, wchodzącej w skład organizacji ARA, 1,2 mln dolarów. $Z$ tej sumy $1 \mathrm{mln}$ był wydatkowany na żywność dla głodujących Powołża, a pozostałe 200 tys. dla potrzebujących Białorusi. Kolejny 1mln 250 tys. dolarów przekazał wiosną 1922 r. z przeznaczeniem dla głodujących dzieci Ukrainy. Kwota ta stanowiła 7/8 całej pomocy ARA ${ }^{10}$. Joint ściśle współpracował z nią zwłaszcza w okresie jej największej mobilizacji od marca do listopada 1922 roku. Przez te miesiące przekazał na fundusz ARA 4 mln 325 tys. dolarów, co stanowiło ponad dziesiątą część całej pomocy przekazanej głodującym $\mathrm{w}$ Rosji ${ }^{11}$. Choć od samego początku było wiadomo, że jest to kropla w morzu potrzeb, to jednak o skali pomocy Jointu świadczy porównanie, że trzecia część pomocy przekazanej przez ARA została pokryta przez kongres amerykański ${ }^{12}$.

Latem 1922 r., w okresie największego głodu, istniało aż 15 tys. stołówek dla dzieci i dorosłych, wydawano wiele milionów suchych kolb kukurydzy. ARA żywiła więcej niż $10 \mathrm{mln}$ osób. Według danych Ludowego Komisariatu Żywności (dalej: Narkomprod) ${ }^{13}$, Joint zakupił wówczas artykuły opiewające na sumę $136 \mathrm{mln}$ złotych rubli. Organizacja ta przez pierwszy rok swojej działalności rozdysponowała 778,8 ton żywności, lekarstw odzieży, w tym 666,6 ton ziarna. Przez ten czas wydała głodującym dzieciom i dorosłym 1,4 mld jednorazowych racji żywnościowych $^{14}$. Dla porównania można zauważyć, że Narkomprod wysłał do głodujących guberni w celu zorganizowania karmienia 6,7 mln pudów żywności i około $5 \mathrm{mln}$ pudów ziemniaków. Dobrowolne datki społeczeństwa radzieckiego wyniosły 10,5 mln pudów ${ }^{15}$. Podane rozmiary pomocy charytatywnej najlepiej obrazują rozmiar udziału tej organizacji w ratowaniu milionów ludzi.

Nowy okres działalności Jointu, jako samodzielnej organizacji, rozpoczął się 11 grudnia 1922 r. po podpisaniu porozumienia z rządem Związku Radzieckiego.

9 Kwakrzy - wspólnota chrześcijańska założona w Anglii w XVII w. Propagując pacyfizm, zajmowała się działalnością charytatywną. Amerykańscy kwakrzy, wchodząc w skład ARA, aktywnie uczestniczyli w pomocy dla głodującej ludności Związku Radzieckiego.

10 CGAOR, f. 1058, op. 1, d. 55, 1. 171, 312.

11 E. M. Chenkin, O roli „Dżonta” w okazanii pomoszczi Rossii i Ukraine v 1921-23 rr., „Vestnik Evrejskogo universiteta w Moskve", 4, 1993, s. 91.

12 CGAOR, f. 1065, op. 3, d. 66, 1. 19; f. 1058, op. 1, d. 55, 1l. 71, 312, 383.

13 Narodny Commissariat Prodovolstviya, Ludowy Komisariat Żywności (w skrócie Narkomprod) był odpowiedzialny od 1918 r. za dostawy żywności i towarów przemysłowych. W czerwcu 1918 r. zorganizował „komitety ubogich”, w których mniej zamożni chłopi mogli być używani jako narzędzie do szpiegowania i późniejszych egzekucji zgromadzonych, ukrytych zapasów ziarna przez „kułaków”- zamożnych chłopów.

14 CGAOR, f. 1058, op. 1, d. 50, 1. 90; d. 95, 1. 59; d. 586, 1. 92; d. 146, 1. 66.

15 E. M. Chenkin, Oczerki istorii borby sovietskogo gosudarstva s gołodom (1921-1922gg), Krasnojarsk 1988, s. 53, 68. 
W tym czasie ARA zaczęła zamykać swoją działalność, Joint zaś dążył do rozszerzenia działalności na Ukrainie i Białorusi, gdzie mieszkała największa liczba ludności żydowskiej ${ }^{16}$. Wówczas zmienił się też charakter pomocy. Główna uwaga została poświęcona wskrzeszeniu ekonomiki rejonów, przede wszystkim rolnictwa oraz pomocy dzieciom i domom dziecka. W porozumieniu $\mathrm{z}$ władzami radzieckimi Joint zadeklarował wydatkowanie $2 \mathrm{mln}$ dolarów, z czego 1,5 mln dolarów na produkty żywnościowe. Na wzór wcześniejszych ustaleń między ARA a rządem ZSRR, zachował możliwość samodzielnego rozprowadzania pomocy i zobowiązał się ją rozdzielać wśród wszystkich potrzebujących (niezależnie od narodowości). Zadeklarował również bliską współpracę z centralnymi i miejscowymi organami władzy. Towary Jointu były zwolnione od ceł, opłat za przewóz rzeczny i kolejowy oraz magazynowych. Pracownicy tej organizacji nie musieli uiszczać opłat kolejowych, mogli bezpłatnie i poza kolejnością korzystać z usług poczty, telegrafu i radia ${ }^{17}$.

Joint aktywnie pomagając dzieciom, które ucierpiały w wyniku wojny domowej i głodu, w końcu 1922 r. utrzymywał 913 domów dziecka, w których przebywało 37,5 tys. dzieci oraz dbał o inne instytucje zajmujące się dziećmi. Miesięcznie na żywienie najmłodszych mieszkańców państwa radzieckiego wydatkował 40 tys. dolarów. Z USA dostarczono tysiące swetrów dziecięcych, dziesiątki tysięcy par pończoch, setki tysięcy łokci wełnianych i lnianych tkanin ${ }^{18}$, ponad 60 tys. płaszczy, sukienek i garniturów oraz 10 tys. par obuwia. Na remonty oraz zapewnienie opału i zabezpieczenie normalnego funkcjonowania domów dziecka wydatkował ponad 200 tys. dolarów ${ }^{19}$. Należy dodać, iż Joint wspomagał także szpitale i laboratoria oraz domy inwalidów. Z jego środków było ponadto organizowane dożywianie, a nawet zakup zeszytów i książek dla licznych szkół zarówno Białorusi, jak i Ukrainy oraz pomoc żywnościowa dla 6,5 tys. studentów uczelni wyższych: Kijowa, Moskwy, Piotrogradu i Odessy ${ }^{20}$. Organizacja troszczyła się także o ludzi kultury i nauki, wykładowców i nauczycieli, dostarczając im żywność i odzież ${ }^{21}$. Łącznie w latach 1921-1924 na wymienioną działalność organizacja wyasygnowała aż 24 mln 500 tys. dolarów ${ }^{22}$.

16 W 1921 r., w czasie wielkiego głodu na Powołżu, Senat USA zatwierdził 20 milionów dolarów na pomoc dla ZSRR. ARA dostarczyła żywność 11 milionom głodujących. Jak podaje Richard Pipers, dzięki pomocy amerykańskiej rząd bolszewicki zaoszczędzone w ten sposób środki własne mógł przeznaczyć na zakup broni za granicą (R. Pipers, Rosja bolszewików, Warszawa 2005, s. 446-448). Pomoc dla ZSRR wstrzymano w 1923 r., gdy ARA odkryła, że ZSRR wznowił eksport zboża (C. M. Edmondson, An Inquiry into the Termination of Soviet Famine Relief Programmes and the Renewal of Grain Export, 1922-23, „Soviet Studies”, Vol. 33, No. 3 (1981), pp. 370-385).

17 CGAOR, d. 263, 1. 82; f. 1065, op. 3, d. 66, 1. 19.

18 Łokieć- tradycyjna miara długości nawiązująca do średniej długości ręki od stawu łokciowego do końca palca środkowego, odpowiadająca w przybliżeniu $51,72 \mathrm{~cm}$.

19 Itogi borby s posledstwami gołoda, Moskva 1924, s. 75, 76.

20 Gosudarstviennyj Archiv Rossijskoj Federacji (Państwowe Archiwum Federacji Rosyjskiej, dalej: GARF); GARF, f. 1064, op. 6, d. 65, 1l. 17, 18, 33; f. 1058, op. 2, d. 367, 1l. 233, 286; Nacjonalnyj Archiv Respubliki Bełarus (Narodowe Archiwum Republiki Białorusi, dalej: NARB), NARB, f. 684, op. 1, d. 61, l. 121.

21 Ibidem, f. 16, op. 1, d. 11, 1l. 23-24.

22 Ibidem, f. 205, op. 5, d. 176, 1. 43. 
Wspominając o stosunku władz do tej zagranicznej organizacji charytatywnej, trzeba zaznaczyć, iż od samego początku spotykała się ona z przeciwdziałaniem władz miejscowych i organizacji partyjnej. U podstaw tych działań leżało dążenie do zachowania politycznego monopolu komunistycznego i zarazem wyłączności na rozprowadzanie pomocy. Niebagatelną rolę odgrywał również strach przed jakąkolwiek formą niezależności organizacji i ruchów społecznych. Niemal jednocześnie, z rozpoczęciem działalności przez organizacje żydowskie, partyjne władze ujezdow i guberni ${ }^{23}$ szybko zaczęły wystosowywać do władz wyższych pełne trwogi pisma. Dotyczyły one nasilenia się syjonistycznej propagandy, wpływu „klerykałów” na biedotę żydowską, marnej pracy sekcji żydowskiej przy gubernianych i ujezdnych komitetach RKP(b $)^{24}$ oraz podjęcia wszelkich możliwych środków w celu przeciwdziałania temu zjawisku.

W grudniu 1922 r., na początku samodzielnej działalności Jointu, przedstawiciel WCIK przy organizacjach zagranicznych rozesłał tajne pismo do swoich podwładnych. Oznajmiając o podpisaniu porozumienia z Jointem, władze przypominały, że Joint jest organizacją burżuazyjną, która chce wejść w kontakt z syjonistami, rabinami, społecznościami religijnymi i pomagać w pierwszej kolejności ludności żydowskiej. Polecano organom miejscowym robić wszystko, aby pomoc odbywała się pod kontrolą organów radzieckich, nakazano szczególnie wnikliwie kontrolować pomoc przydzielaną inteligencji żydowskiej (lekarzom, prawnikom itp.), nie dopuszczać do udziału organizacji religijnych w rozprowadzaniu pomocy zagranicznej ${ }^{25}$. Dodatkowo w tajnej dyrektywie zachęcano do działań naruszających porozumienie z Jointem, które przewidywało niezależność tej organizacji w rozprowadzaniu swoich resursów i prawo zakładania w tym celu komitetów społecznych ${ }^{26}$.

W warunkach tamtego okresu, nawarstwienia sprzeczności społecznych i walki politycznej, działalność Jointu była zarzewiem konfliktowych sytuacji. Organizacja świadoma reakcji władz radzieckich wyraziła więc zgodę, aby w komisjach dla rozprowadzania przesyłek zbiorowych uczestniczyli przedstawiciele miejscowych komisji pomocy głodującym ${ }^{27}$. W wielu miastach Białorusi powstawały społeczne komisje żydowskie rozdawnictwa pomocy zagranicznej. Ich skład nie zapobiegł jednak oskarżeniom, które dochodziły nawet do Prezydium WCIK $^{28}$. W wielu skargach miejscowych organizacji partyjnych donoszono, iż w skład komisji żydowskich nie wchodzi ani jeden komunista, a tylko rabini, mienszewicy i syjoniści. Intencje polityczne tych skarg były aż nadto jasne. Takich przykładów można przytoczyć wiele 29 .

23 Zachowuję terminologię języka rosyjskiego, która wiernie oddaje klimat tamtego okresu. Odpowiada ona polskim powiatom i województwom.

24 RKP(b), Rosyjska Komunistyczna Partia (bolszewików).

25 NARB, f. 1058, op. 1, d. 43, 1. 2.

26 Ibidem, d. 263, 1. 82.

27 Ibidem, d. 67, 1. 96.

28 Ibidem, d. 1235, op. 97, d. 67, 1.3; WCIK - Wszechrosyjski Centralny Komitet Wykonawczy, w czasie rewolucji rosyjskiej 1917 r. organ dwuwładzy w Rosji. Po przejęciu władzy przez bolszewików w latach 1917-1937 de iure najwyższy organ władzy w Związku Radzieckim.

29 Ibidem, f. 1058, op. 1, d. 59, 1. 27. 
Joint od początku aktywności w ZSRR działał w kontakcie z Ewobszczestkom. Był to społeczny komitet pomocy ludności żydowskiej, która ucierpiała od pogromów w czasie wojny domowej, założony w $1920 \mathrm{roku}^{30}$. Była to bezpartyjna społeczna organizacja, która odegrała znaczną rolę w zbiorze środków za granicą, zwłaszcza wśród ludności żydowskiej USA. Wkrótce jednak na tle walki politycznej doszło do sytuacji konfliktowej. W 1922 r. WCIK całą pomoc dla ludności żydowskiej polecił przeprowadzać przez Ewobszczstkom, ograniczając udział inteligencji i zaostrzając kontrolę nad działalnością organizacji zagranicznych ${ }^{31}$.

O skali narastającego konfliktu najlepiej świadczy wystąpienie zastępcy narodowego komisarza do spraw narodowości w Prezydium WCIK, dotyczące aktywizacji syjonistycznych i klerykalnych elementów w rejonach działalności ARA i Jointu ${ }^{32}$. Było ono oparte na licznych zawiadomieniach Ewobszczstkoma. W grudniu $1922 \mathrm{r}$. oskarżano kierownictwo Jointu o utrudnianie wprowadzenia w zestaw komitetów pomocy miejscowych przedstawicieli ispołkomów i skupianie wokół siebie „podejrzanych działaczy społecznych”. Zwracano uwagę, iż w skład komitetów wchodzą rabini i przedstawiciele inteligencji ${ }^{33}$. Przytoczone $\mathrm{w}$ informacjach zjawiska ilustrują niejako tylko jedną stronę procesu historycznego. Podobne dokumenty odzwierciedlają nieprzychylność do innej ideologii i ruchów społecznych, nerwową reakcję na wszelkie niezależne od władz radzieckich poczynania Jointu oraz ARA. Dotyczą one też niesprawiedliwego, zdaniem organizacji partyjnych, przydzielania pomocy wszystkim potrzebującym - w tym inteligencji. W zaistniałej sytuacji Joint dążył do autonomii politycznej komitetów żydowskich i członkostwa osób cieszących się autorytetem wśród ludności. W środowisku żydowskim byli to rabini i nauczyciele jesziwów oraz syjoniści (wówczas to pojęcie nie miało jednoznacznego znaczenia). Należy też mieć na uwadze aspekt psychologiczny. Przybyli z zagranicy przedstawiciele Jointu sympatyzowali z religijnymi i inteligenckimi kręgami społeczności żydowskiej. Większość z nich podejrzliwie odnosiła się do organów władz radzieckich, nie dowierzała im. $Z$ drugiej strony pojawienie się Jointu aktywizowało religijne i społeczno-narodowościowe organizacje, które były prześladowane przez władze radzieckie. Wśród pracowników Jointu i ARA byli bowiem też i przeciwnicy władzy, którzy chcieli wykorzystać pomoc zagraniczną dla jej osłabienia. Nie to jednak było najważniejsze w działalności tych organizacji. Znacząca była walka z kryzysem o uratowanie milionów ludzi od śmierci głodowej.

Chcąc przybliżyć długoterminową działalność Jointu, zwłaszcza udział w osadnictwie żydowskim na obszarze Białorusi, tytułem wstępu należy zauważyć, iż Żydzi byli w Rosji carskiej narodem szczególnym pod względem dotyczącego ich obostrzenia zakupu bądź dzierżawy ziemi poza granicami miast i miasteczek. W rezultacie, w kraju, w którym rolnicy stanowili 86\% ogółu ludności, tylko około 50 tys. Żydów

30 Evobszczectkom - Evriejskij Obszczestviennyj Komitet - Żydowski Komitet Społeczny.

31 Ibidem, 1. 39.

32 Ibidem, f. 1235, op. 97, d. 58, 11. 1, 6.

33 Ibidem, f. 1058, op. 1, d. 265, 1l. 1, 2, 5, 9, 10, 16. 
zajmowało się uprawą roli. Ten stan rzeczy zaczął się stopniowo zmieniać dopiero po rewolucji październikowej ${ }^{34}$.

W końcu 1921 r. w Moskwie miał miejsce Ogólnorosyjski Zjazd Kołchozów i Sowchozów. W jego organizację zaangażowana była pierwsza w ZSRR żydowska organizacja społeczna, Związek Żydowskich Mas Pracujących, która zainicjowała pracę nowych żydowskich arteli i komun rolniczych (dalej: Setmass) ${ }^{35}$. W rezolucji zjazdu odnotowano: „jednym ze środków produktywizacji żydowskich mas jest ich agraryzacja drogą zakładania arteli... najlepszym potwierdzeniem (słuszności tej tezy) są istniejące żydowskie artele i komuny, zorganizowane przez Setmass" np. w okręgu połockim ${ }^{36}$.

Po tej rezolucji, na osobiste polecenie Włodzimierza Lenina, przewodniczący Żydowskiego komisariatu przy Narkomnacie - Ludowym Komisariacie Narodowości - Szymon Dimansztejn oraz Szmuel Żydowiecki przygotowali referat, po wysłuchaniu którego Komitet Centralny (dalej: CK) uznał za pożądane zajęcie się przez masy żydowskie uprawą roli ${ }^{37}$.

Tymczasem nowo powstałe kolonie przeżywały pierwsze trudności związane z suszą. Na pomoc im pospieszył Ewobszczestkom, który przesłał osiedleńcom 10 tys. pudów nasion. Rozpoczęto prace melioracyjne, skierowano do obsługi nowych rolników doświadczonych agronomów. W raportach wskazuje się, że tylko dzięki tej energicznej akcji te kolonie uratowano ${ }^{38}$.

Trudne początki istnienia kolonii żydowskich przyczyniły się do działań mających na celu współudział w osadnictwie żydowskim rozmaitych organizacji. W maju 1923 r. do tej akcji włączono ORT ${ }^{39}$ i zaproponowano mu przekazanie, na ściśle ustalonych warunkach, szeregu kolonii znajdujących się w krytycznym położeniu. Joint natychmiast zaproponował ORT przekazanie środków niezbędnych dla ratowania gospodarstw. Dodatkowo zgłosił możliwość finansowania w wysokości $50 t y s$. dolarów konkretnych prac związanych z instalacją kolonistów oraz zaopatrzenia ich w żywy inwentarz i narzędzia rolnicze. Jednocześnie zaznaczył, iż należy tę sumę traktować jako wstępną, gdyż w miarę ponoszonych kosztów może być ona zwiększana $^{40}$.

$\mathrm{Na}$ naradzie przedstawicieli Jointu, $\mathrm{EKO}^{41}$ i ORT podczas rozpatrywania problemów gospodarstw żydowskich wokół miast i miasteczek postanowiono, że ORT

34 Dotąd zadania organizacji charytatywnych ograniczały się do pomocy żywnościowej i odzieżowej dla głodującej ludności. Joint, jako pierwszy, już w 1922 r. przystąpił do planowej odbudowy rolnictwa. W porównaniu z ogromnymi rozmiarami biedy, pomoc ta nie miała rozstrzygającego znaczenia. Nie ulega jednak wątpliwości, że był to wielki wkład w zwalczanie głodu. Setki tysięcy ludzi przeżyło dzięki tej pomocy.

35 Sojuz Evrejskich Trudjaszczichsja Mass - Setmass; „Nakanunie”, nr 12-13, 15 III 1921, s. 16.

36 Sbornik statej po evriejskoj istorii i literaturze, t. 2, cz. 1, Israel 1992, s. 219.

37 J. W. Golde, Zemelnoe ustrojstwo trudjaszczichsja evreev, Moskva 1925, s. 4.

38 NARB, f. 684, op. 1, d. 1, 1. 30.

39 ORT - Obszczestvo Remieslennogo Truda - Towarzystwo Pracy Rzemieślniczej.

40 NARB, f. 687, op. 2, d. 7, 1. 67-68.

41 EKO - Evriejskoje Kolonizacjonnoje Obszczestwo - Żydowskie Towarzystwo Kolonizacyjne. 
weźmie na siebie większość pomocy, z wyjątkiem gospodarstw, których głównym źródłem utrzymania są rośliny wieloletnie (sady, winnice, uprawy chmielu itp.). Ten sektor pozostawiono w dyspozycji Jointu. Organizacja ta zarezerwowała sobie prawo wprowadzenia nowych odmian roślin i możliwość przekazania ich w przyszłości pod opiekę ORT. Nad rozmiarem i warunkami udzielanego kredytu przez współpracujące organizacje, miała czuwać komisja, w skład której wchodził jeden przedstawiciel każdej z nich. Ponadto każda $\mathrm{z}$ organizacji miała prawo do własnego - instruktorskiego i inspekcyjnego - personelu ${ }^{42}$. O pozytywnych wynikach współpracy najlepiej świadczyło utrzymanie się, a nawet okrzepnięcie nowo powstałych gospodarstw.

1 listopada 1923 r. Joint zaprzestał działalności na rzecz pomocy osadnikom żydowskim, a jego miejsce zajął Agro-Joint ${ }^{43}$. W praktyce Zjednoczenie Agronomicznych Korporacji Żydów Ameryki podjęło działalność w Związku Radzieckim w lipcu 1924 roku$^{44}$.

Należy dodać, że był to czas sprzyjający pracy tej organizacji w Kraju Rad. Z jednej strony osłabła bowiem blokada Rosji radzieckiej ze strony Ententy, a z drugiej potęgował się nacisk międzynarodowej społeczności żydowskiej chcącej pomóc Żydom w ZSRR. Aby uniknąć wszelkich nieporozumień, przedstawiciele Agro-Jointu nieustannie podkreślali, że nie mają zamiaru uprawiać jakiejkolwiek propagandy i mieszać się w wewnętrzne sprawy młodego państwa radzieckiego. Wskazywali, iż są organizacją całkowicie apolityczną, w tym także, jeśli idzie o politykę ekonomiczną realizowaną wobec ludności żydowskiej. Akcentowali, że osadnictwo rolne mniejszości żydowskiej nie jest wynikiem ich inicjatywy. Nie organizują kooperatyw, nie określą warunków ich pracy, a tylko uczestniczą we współpracy z już sformowanymi i legalnie działającymi wspólnotami rolnymi. Ich głównym zadaniem jest kadrowe, techniczne i finansowe wsparcie kolonii żydowskich. Jednocześnie zaznaczali, że kolonizację trzeba uznać za drogę ocalenia ludzi, wybór życia nad śmiercią, a osadnictwo rolne nie powinno być tematem teoretycznych sporów ${ }^{45}$.

Wspominając o działaniach podejmowanych przez władze radzieckie na początku lat dwudziestych, wypada stwierdzić, że odzwierciedlały one nadzieje ich członków na pozyskanie międzynarodowej pomocy dla projektu osadnictwa żydowskiego. Najlepszym tego dowodem jest postanowienie z 29 września 1924 roku. Prezydium Centralnego Komitetu Wykonawczego ${ }^{46}$ (na wniosek Prezydium Rady Narodowości) o powołaniu

42 NARB, f. 684, op. 1, d. 42, 1. 45.

43 Amerykańskie Żydowskie Zjednoczenie Agronomicznych Korporacji, Amerikanskaja Evrejskaja Obedinennaja Korporacija (dalej: Agro-Joint).

44 Ibidem, f. 11, op. 2, d. 20, 1. 1; zob. też: M. Micel, Posleniaja głava. Agro-Dżojnt v gody Bolszogo tierrora, Kiiv 2012.

$45 \mathrm{Dr}$ J. Rosen mówił o apolitycznych celach organizacji przy wielu okazjach, m.in. na konferencji organizacji żydowskich uczestniczących w pomocy Żydom radzieckim w Filadelfii 12-13 września 1925 r., o referacie w: E. Joffe, B. Mielcer, Dżoint v Biełorusi, Minsk 1999, s. 59-60.

46 Centralnyj Ispołnitielnyj Komitet - CIK. 
Komitetu osadnictwa Żydów na rolii ${ }^{47}$ przy Prezydium Rady Narodowości CIK ZSRR na czele z P. G. Smidowiczem. Do rady weszło wielu działaczy komunistycznych znanych za granicą, np. zastępca komisarza spraw zagranicznych M. M. Litwinow. Władze KOMZETU, chcąc pozyskać poparcie społeczne i pomoc zagraniczną dla tego unikalnego w skali ZSRR projektu, zdecydowały o powołaniu Towarzystwa osadnictwa rolnego Żydów pracujących (dalej: OZET) ${ }^{48}$, które miało skupiać nie tylko Żydów, ale też pozyskać dla przedsięwzięcia masy pracujące innych narodowości. Na pierwszym posiedzeniu tej organizacji mówił o jej zamierzeniach J. Łarin - przewodniczący Centralnego Zarządu OZET. Podkreślał on, że wyłącznym celem OZET jest pomoc w osadnictwie rolnym społeczności żydowskiej. Zadaniem organizacji nie jest ani walka $\mathrm{z}$ religią, ani syjonizmem, swoją działalność ogranicza tylko do pracy wśród rolników żydowskich. OZET jednak nie jest organizacją żydowską, lecz wszystkich obywateli, którzy czynnie sprzyjają inicjatywie osadnictwa Żydów na roli ${ }^{49}$.

Postanowiona przez Komitet Centralny RKP w 1924 r. akcja kolonizacyjna była fragmentem integracyjnej polityki narodowościowej. Miała ona m.in. sprzyjać uformowaniu się w społeczności żydowskiej warstwy chłopskiej, a więc transformacji jej kultury w kierunku zespolenia $\mathrm{z}$ wielonarodowym społeczeństwem radzieckim. Aby zmienić jej ciężką sytuację bytową i jednocześnie „uproduktywnić”, postanowiono przesiedlić tę mniejszość nazywaną „izbytocznoje nasielenije” na wolne ziemie uprawne, które pozostały po nadzieleniu chłopów ukraińskich i białoruskich. Praktyka przesiedleń rolniczych przewidywała:

- rozpoznanie rejonu przesiedlenia,

- przedyskutowanie problemów związanych z przesiedleniem z organami władz miejscowych,

- formalne spisanie porozumień,

- przejazd przesiedleńców.

Przyszli rolnicy, „chodoki”, jak ich nazywano, z wyprzedzeniem byli uprzedzani o przesiedleniu na wolne ziemie. Po zarejestrowaniu decydujących się na pracę na roli tzw. delegaci rolni formowani w kolektywy otrzymywali „chodaczeskije” dokumenty. Były to zaświadczenia, że dany człowiek jest członkiem przyszłego kolektywu lub towarzystwa rolnego, ma status prawny i jest chroniony przez państwo. Oprócz tego wszystkie organy władz miejscowych w rejonach przesiedlenia były zobowiązane doradzać przesiedleńcom w wyborze dogodnych działek. „Chodaczeskije” zaświadczenia obowiązywały przy nadawaniu małych nadziałów ziemi z kolonizacyjnych rezerw - fondów w oznaczonych guberniach. Dokumenty te były ważne przez dwa miesiące od dnia wystawienia. Do czasu powrotu „chodoka” $\mathrm{z}$ adnotacją o zarejestrowaniu przez niego nadziału ziemi, nie była dopuszczalna likwidacja jego gospodarstwa w miejscu poprzedniego zamieszkania.

47 Komitet po ziemielnomu ustrojstvu Jevriejev - KOMZET - Komitet osadnictwa rolnego Żydów. 48 Obszczestwo po ziemelnomu ustrojstwu trudjaszczichsja ewreew - OZET - Towarzystwo Osadnictwa rolnego pracujących Żydów.

49 Pierwszy Ogólnozwiązkowy Zjazd OZET, Moskwa 1927, s. 35. 
Każdy kandydat na rolnika miał czas do 1 sierpnia następnego roku, aby się przesiedlić na zarejestrowaną ziemię. Trzeba dodać, iż po upływie tego terminu tracił prawo do zarejestrowanego nadziału ziemi. Zabronione też było, na skutek rozmaitych dróg losowych, np. nieszczęśliwego wypadku, przekazywanie zarejestrowanej działki innym osobom nieuwzględnionym w zaświadczeniu. Po przybyciu na przydzieloną ziemię "chodaczeskoje” zaświadczenie było zastępowane przez tymczasowy dokument przesiedleńczy w okręgowym oddziale ziemskim. Po spełnieniu tych formalności przesiedleniec stawał się pełnoprawnym właścicielem zarejestrowanej przez niego działki ziemi.

Wszyscy mający podjąć pracę na roli musieli jednak spełniać określone warunki wyznaczone przez władze. Od przesiedleńców wymagano np., aby w rodzinie złożonej z pięciu członków były co najmniej trzy osoby pracujące. Jednocześnie każda rodzina winna posiadać nie mniej niż 500 rubli na zagospodarowanie. Jedynie dla Żydów zrobiono kilka wyjątków odnośnie do zestawu rodziny i jej zabezpieczenia finansowego. Zgodnie z wytycznymi, od Żydów mających liczne rodziny wielopokoleniowe wymagano, aby z rodziny pracowały nie mniej niż dwie osoby.

$\mathrm{W}$ celu rozeznania wielkości kosztów, jakie będzie zmuszone wyasygnować państwo, udzielając przesiedlanym kredytu kolonizacyjnego, rodziny podzielono na pięć kategorii: te, co miały 100 rubli na zagospodarowanie, 150, 300, 500 i te najzamożniejsze, które, mogły na własny koszt się przesiedlić. W większości uprawą roli miała się zajmować przede wszystkim biedna część społeczności żydowskiej, której była potrzebna pomoc. Na przykład z 1696 rodzin, które zarezerwowały ziemię na obszarach Krzywego Rogu w 1925 r., od 10 do 150 rubli miało 66\%, 20\% z nich miało 300 rubli, a tylko 9\% - 500 rubli. Pozostałe 5\% mogło się przesiedlić na własny koszt.

Interesująca była forma kierowania dzieloną ziemią. Na czele każdego nadziału stał agronom, który odpowiadał za wykonanie wszystkich prac: poczynając od budownictwa mieszkaniowego i gospodarczego, przez kredytowanie gospodarstw, buchalterię, organizację wewnętrzną, aż po sprawy sporne w pracy. Agronom był też jedyną osobą ponoszącą prawną odpowiedzialność za wszelkie poczynania grupy $^{50}$.

25 lipca 1924 r. została powołana postanowieniem Prezydium CIK BSSR Komisja Osadnictwa Rolnego Żydów Pracujących przy prezydium CIK BSSR ${ }^{51}$. Miesiąc później 29 lipca, CIK i SNK BSSR ${ }^{52}$ zatwierdziły statut oraz 5 członków i 2 kandydatów komisji ${ }^{53}$. Po roku, 25 lipca 1925 r., zaczął funkcjonować Białoruski Oddział Towarzystwa Osadnictwa Rolnego Żydów Pracujących w ZSRR (dalej: Biełozet) ${ }^{54}$.

50 Duża odpowiedzialność agronoma wiązała się zwłaszcza ze współpracą z Agro-Jointem, która niezwykle aktywnie od lipca 1924 r. współuczestniczyła w rolnej akcji osiedleńczej ludności żydowskiej.

51 NARB, f. 6, op. 1, d. 351, t. 1, 1. 377.

52 Soviet Narodnych Komisssarov - SNK - Rada Komisarzy Ludowych.

53 NARB, f. 6, op. 1, d. 298, 1. 186-187.

54 Biełorusskoe otdelenie Obszczestva po ziemleustrojstvu trudjaszczichsja evreev w SSSR Bełozet; NARB, f. 11, op. 1, d. 29, 1. 5, 11-13. Na początku 1926 r. Biełozet zorganizował oddziały 
Według ówczesnego podziału administracyjnego Białorusi na osiem okręgów (Bobrujski, Witebski, Chomelski, Miński, Mochylewski, Mozyrski, Orszański, Połocki) istniało 235 żydowskich kolektywów rolniczych ${ }^{55}$. Skupiały one 8538 członków, którzy uprawiali 32342 ha ziemi. W końcu 1924 r. istniało już 311 żydowskich kolektywów. Analizując dane statystyczne, należy dodać, iż ta liczebność kołchozów w zestawieniu z całkowitą liczebnością rolników żydowskich wynosiła aż 45\%, podczas gdy te same szacunki odnoszące się do ludności ZSRR sięgały rzędu zaledwie $1 \%{ }^{56}$.

Kolektywy żydowskie nie były wielkimi gospodarstwami. W większości zrzeszały one od 7 do 20 członków, którzy pracowali np. w gospodarstwach sadowo-ogrodowych na obszarze zaledwie 4-6 ha ziemi. Wielkich gospodarstw, jak np. „Krasnaja wieża”, w której pracowało 72 członków na obszarze 560 ha, było niewiele. Pośrednio, takie stosunkowo niewielkie nadziały ziemi wynikały z faktu, że osiedleńcy byli niedostatecznie zabezpieczeni w żywy inwentarz, zwłaszcza w zwierzęta pociągowe: konie, woły czy nawet krowy. Wedle deklaracji, to KOMZET miał zapewnić dostarczenie żywego inwentarza dla osiedleńców. Najbiedniejsi mieli dostawać konie i krowy na kredyt. W praktyce przyznany gospodarstwom inwentarz nie pokrywał zapotrzebowania i w związku $\mathrm{z}$ tym dochodziło do rozmaitych paradoksów. Nierzadko zdarzało się, że jedna krowa przypadała na dwie lub więcej rodzin $\mathrm{Z}$ takim zbiorowym przydziałem wiązały się problemy z karmą dla krowy, gdyż nie wiadomo było, kto jest jej właścicielem. Bez przydziału, przyznawanego wyłącznie właścicielowi, mogła jej nie karmić żadna z rodzin. Osadnicy żydowscy duże braki odnotowywali również w martwym inwentarzu niezbędnym zarówno do uprawy roli, jak i przeżycia.

Na skutek gospodarczej rzeczywistości przesiedlanych, która była znacznie trudniejsza, niż to wynikało z wcześniejszych deklaracji władz, przygotowania do wiosennych zasiewów zaczęły się ze znacznym opóźnieniem. Do tego dochodziła sytuacja psychologiczna: brak nawyku do pracy na roli, przerażenie wywołane brakiem potrzebnych umiejętności oraz nieznane, nie zawsze przychylne otoczenie społeczne. Mimo niedostatków i rozmaitych przeciwności losu wysiłek wsiedlanych włożony

OZET zarówno w centrach okręgów, jak i mniejsze komórki w miastach oraz miasteczkach. Ibidem, f. 11, op. 1, d. 5, 1. 31

55 Trudno w krótkiej formie artykułu omówić sytuację wsi białoruskiej. Aby zapoznać się szerzej z problematyką, patrz np. szereg artykułów Joanny Gierowskej-Kałłaur, np.: Polacy i Białorusini we wzajemnych opiniach w latach 1918-1921, „Studia z Dziejów Rosji i Europy Środkowo-Wschodniej” 42, 2007, s. 35-66; Straż Kresowa wobec kwestii białoruskiej. Deklaracje i praktyka, „Studia z Dziejów Rosji i Europy Środkowo-Wschodniej”, 44, 2009, s. 21-63; Aktywność środowisk polskich w Mińszczyźnie w realiach lat 1919-1920, „Studia z Dziejów Rosji i Europy Środkowo-Wschodniej”, 45, 2010, s. 91-122; praca Małgorzaty Ruchniewicz, Wieś zachodniobiałoruska 1944-1953. Wybrane aspekty, zwłaszcza rozdział pierwszy poświęcony wsi Kresów Północno-Wschodnich II RP i BSRR w okresie międzywojennym, oraz literatura rosyjskojęzyczna, m.in. T. V. Privałova, Byt rossijskoj derevni 60-e gody XIX-20-e gody XX w., Moskva 2000, N. A. Ivnickij, Repressivnaja polityka sovietskoj vłasti $v$ derevne (1928-1933), Moskva 2000.

56 J. W. Golde, op. cit., s. 10. 
w zagospodarowanie był ogromny. Aktywny członek Agro-Jointu, dr Braun, donosił: „w czasie podróży po Rosji wśród setek kolonistów, z którymi rozmawiałem, nie słyszałem, żeby ktoś się żalił, chociaż rozumiałem, że większa część z nich będzie musiała przeżyć do pierwszych zbiorów na suchym, czarnym chlebie" 57 .

W pierwszym roku przesiedleńcy starali się przede wszystkim obsiać swoją ziemię, a dopiero potem zajmowali się budową domów. Według projektu KOMZETU, dla każdej rodziny przewidywano budowę tymczasowej ziemianki. Rychło jednak Agro-Joint, pozyskawszy przychylność KOMZETU, przygotował swój projekt już pełnowartościowego domu, $\mathrm{z}$ dachem i strychem, droższego od ziemianki zaledwie o 30 rubli $^{58}$. Trzeba zaznaczyć, iż pokrycie dopełniających kosztów budowy brała na siebie organizacja Agro-Joint ${ }^{59}$. Nie bacząc na wszystkie biurokratyczne trudności, zbudowano wiele wygodnych domów i położono fundamenty pod następne. Osiedla żydowskie odróżniały się od innych tym, że budowa domów i pomieszczeń gospodarczych była przemyślana i odpowiadała potrzebom rolników. Agro-Joint musiał jednak nieustannie walczyć ze stale wzrastającymi dopłatami do kosztów budowy, domagając się nie tylko rozliczeń, ale też ich uzasadnienia ${ }^{60}$.

Przedstawiciel Agro-Jointu, prof. A. Fabrikant, który wiosną 1925 r. wizytował żydowskie kolektywy, tak konstatował: „W analizie układu gospodarstw żydowskich, które tylko co zaczęły się rozwijać, łatwo zaobserwować oznaki mądrego podejścia do sprawy upraw"61. Oficjalnie pozytywnie ocenił podejście władz radzieckich do problemu ludności żydowskiej w ZSRR i jej agrokulturyzacji.

Wyrazem docenienia przez władze centralne wielkiego zaangażowania żydowskich rolników była decyzja o zakupieniu dla nich traktorów. Rychło, po ich dostarczeniu, okazało się jednak, że pełne wykorzystanie mocy traktorów odbiega od oczekiwań. Kierowcy przeszli bowiem zaledwie sześciotygodniowe przeszkolenie. Ich umiejętności były zatem niewielkie. Dodatkowo dużo czasu zajmowały wyjazdy po paliwo, którego baza znajdowała się w centrum rejonu. Nie była ponadto zorganizowana regularna dostawa wody, niezbędna do pracy maszyn. W rezultacie traktory obrabiały dziennie tylko 1 des. ziemi. Należy też dodać, iż traktorzyści otrzymujący dzienną zapłatę nie byli zainteresowani większym wysiłkiem. Ich brak umiejętności oraz solidności pracy nierzadko stawał się przyczyną okresowego zatrzymania prac polowych.

Żydowscy przesiedleńcy, chcąc jak najszybciej wykonać potrzebne czynności, podejmowali decyzje na zebraniach kolektywów o zaniechaniu nieracjonalnego wykorzystania techniki. W rezultacie kroków podjętych przez władze wyższe

57 Centralnyj Gosudarstviennyj Archiv Obszczestviennych Organizacji (dalej: CGAOO); CGAOO, f. 1, op. 20, d. 2020, 1. 82 .

58 Dyrektor oddziału rosyjskiego Agro-Jointu, J. Rozen, podpisał 16 grudnia 1924 r. porozumienie o współpracy z KOMZET. NARB, f. 16, op. 1, d. 1, 1. 59.

59 Dużo wysiłku w opracowanie i wprowadzenie w życie nowego projektu włożył agronom S. Lubarski, pracownik departamentu rolnictwa Agro-Jointu.

60 CGAOO, f. 1, op. 20, d. 2784, 1. 94.

61 Ibidem, f. 1, op. 20, d. 2020, 1. 42. 
zespoły traktorowe wraz z bazami remontowymi zostały przekazane przesiedleńczym kolektywom. Na efekty nie trzeba było długo czekać. Wkrótce zaczęła wzrastać wydajność pracy traktorzystów - w ciągu 10-godzinnego dnia pracy obrabiali 2-3 des. ziemi.

Starając się zobrazować podejście Żydów do pracy na roli, A. Fabrikant pisał: „Nie związani rutyną i przebrzmiałymi tradycjami nowi rolnicy żydowscy na miarę swoich sił i możliwości starali się wnieść w swoje gospodarstwo rozwój techniczny. Otwarty umysł, wrodzona przedsiębiorczość i kulturowe nawyki mieszkańców miast pozwalały na szybkie przyswojenie rozmaitych porad ekonomicznych. Rzadko gdzie można spotkać takie zainteresowanie pracą rolniczą, jak w grupie żydowskiej. Każda akcja oświatowa, spotkanie w sprawach rolnych lub budowa biblioteki rolniczej znajduje żywe zainteresowanie i traktowana jest z należytą uwagą"62.

Przytoczona opinia najlepiej świadczy, iż przesiedleńcy poważnie myśleli o pracy na roli. Obala ono zarazem powszechne pomówienia o tymczasowość żydowskiego zainteresowania ziemią i o rychłe, masowe ucieczki z gospodarstw. Opuszczanie ziemi w pierwszym okresie osiedlenia przez żydowskich rolników było bowiem czasowe ze względu na brak miejsc do zamieszkania. Po przerwie zimowej następował ich powrót na przygotowaną jesienią ziemię, dalsze prace rolne, budowa domu i instalacja na stałe.

Staranne tworzenie przez żydowskich osadników podstaw przyszłego gospodarstwa, wykorzystywanie traktorów i innej techniki, wreszcie pomoc rolnikom innych narodowości sprzyjało zmianie, początkowo negatywnego stosunku ludności miejscowej do nowych osadników. Używanie traktorów w pracach polowych przez żydowskich przesiedleńców wręcz porażało ludność miejscową, która nigdy dotąd nie widziała zastosowania takich maszyn w pracach polowych. Osłupienie wywoływane pracą maszyn rodziło zarówno zazdrość, jak i szacunek. Traktory były synonimem prestiżu odzwierciedlającego w oczach miejscowych rolników stosunek władz do nowych osadników. Można wręcz mówić o mitologii traktora będącej wyrazem zarówno skoku kulturowego, cywilizacyjnego, jak i narzędziem władzy. Ewolucja postaw wobec żydowskich przesiedleńców była tym bardziej znacząca, że w tym okresie emocje budził np. problem „Trostjaneckogo”, „Kaniewskogo”, "Pokrowskiego dieła”. Były to konflikty wynikające z zagospodarowania ziemi przeznaczonej dla osadników żydowskich przez ludność miejscową. Przykłady można mnożyć: Żydzi, próbując się bronić, zaczęli zakładać oddziały samoobrony. Aby nie dopuścić do zaostrzenia sytuacji, potrzebna była interwencja wysokich władz państwowych. Władze miejscowe bowiem nierzadko przymykały oczy na samowolne przywłaszczanie ziemi przez miejscowych „kułaków”63.

W 1925 r. Agro-Joint sfinansował pomoc dla 3179 rodzin żydowskich osadników w wysokości 1600000 rubli $^{64}$. O wielkości wkładu najlepiej świadczy sprawozdanie

62 CGAWO, f. 413, op. 1, d. 10, 1. 70.

63 Ibidem, f. 505, op. 1, d. 113, 1. 106.

64 NARB, f. 11, op. 1, d. 9, 1. 237. 
Ewbjuro CK KP(b)B za styczeń-maj 1925 r., w którym mowa, że EKO oraz Joint odegrały główną rolę $\mathrm{w}$ kredytowaniu i rozdzielaniu pomocy finansowej pośród żydowskich osadników ${ }^{65}$.

Na obszarze całej Białorusi Joint zaopatrzył żydowskich osadników w 12 traktorów, 152 siewniki, 151 żniwiarki 152 młockarnie ${ }^{66}$. Obszary uprawne wypełniały w większości zasiewy zbóż, pozostała część przeznaczana była na łąki i pastwiska oraz w nieznacznym stopniu na kultury techniczne. We wszystkich gospodarstwach istniała hodowla zwierząt lub drobiu, jednak tylko w pojedynczych były fermy świń. Pomimo pracy włożonej w uprawę roli czy hodowlę, dla wielu gospodarstw sadownictwo było głównym źródłem dochodu. Na Białorusi specjalizowały się w nim głównie dwa okręgi: mozyrski i homelski.

Polityka narodowościowa państwa popierająca ekonomiczny rozwój gospodarstw żydowskich sprzyjała wzrostowi liczebności kolonistów i zarazem powiększaniu się obszarów ziemi, którą uprawiali. W 1926 r. odnotowano już czterokrotny wzrost obszaru ziemi skupionej w rękach rolników żydowskich ${ }^{67}$. Wedle dokumentów znajdujących się w Archiwum Narodowym Republiki Białoruś, tylko na Białorusi w 1926 r. istniało 145 znaczących, żydowskich kolektywów skupiających 40 tys. członków. Dane te wskazują, że 12,5\% żydowskiej mniejszości na tym obszarze zajmowało się rolnictwem ${ }^{68}$. Tak masowe osadnictwo było możliwe w znacznym stopniu dzięki pomocy ze strony Agro-Jointu. Tylko w tym roku wydatkował on na cele instalacji kolonistów aż $2 \mathrm{mln}$ rubli69. Należy dodać, że suma ta nie uwzględnia pomniejszych wydatków, np. na 440 tys. kubików drewna zakupionego na budowę zagród $^{70}$.

30 stycznia 1927 r. Sownarkom SSSR zatwierdził porozumienie o współpracy KOMZETU z Agro-Jointem na kolejny rok ${ }^{71}$. Miesiąc później (22 lutego) na posiedzeniu KOMZET SSSR z Agro-Jointem zawarto umowę w sprawie zaopatrzenia osadników w większą liczbę traktorów ${ }^{72}$. Po podpisaniu powyższych dokumentów do Mińska przybył (31 maja) dyrektor Agro-Jointu w Związku Radzieckim, dr Joseph A. Rozen, oraz dwaj jego pomocnicy, Samuel E. Liubarskii i Krojew. Chcieli oni bezpośrednio, na miejscu zapoznać się z rzeczywistą sytuacją żydowskich kolonistów na

65 Ibidem, f. 4, op. 10, d. 39, 1. 160-161.

66 E. Joffe, B. Melcer, op. cit., s. 58-59.

67 Był to stosunek 42000 des. do 10200 des. przed rewolucją; NARB, f. 4, op. 10, d. 39, 1. 80.

68 Ibidem, f. 255, op. 2, d. 27, 1. 57.

69 Ibidem, f. 11, op. 1, d. 9, 1. 237.

70 Ibidem, f. 11, op. 1, d. 66, 1. 15.

71 Należy dodać, iż władzom radzieckim zależało na współpracy z Agro-Jointem. Wyrazem zainteresowania było wprowadzenie do żydowskich oddziałów szkół partyjnych wykładów poświęconych polityce ekonomicznej i geografii gospodarczej z uwzględnieniem działalności Agro-Jointu jako formy pomocy dla ludności żydowskiej, ibidem, f. 4, op. 1, d. 49, 1. 18021. O tym, że współpracą była zainteresowana również druga strona, świadczyła wizyta prezesa Agro-Jointu, Feliksa Wartburga, przybyłego do Moskwy w 1927 r. Jego wrażenia z podróży do ZSRR zostały opublikowane w Biuletynie żydowskiej agencji telegraficznej, ibidem, f. 11, op. 2, d. 20, 1. 2.

72 Ibidem, f. 11, op. 1, d. 66, 1. 7. 
Białorusi. Odwiedzili oni rolników w orszańskim rejonie oraz we wsi Komzetowka niedaleko Mińska. Pod koniec inspekcji odbyli też rozmowy z Narkomziemom D. F. Piszczepowym i przedstawicielem Bełozet-a i BełOrt-a. Spotkania dotyczyły form dalszej współpracy, zwłaszcza koniecznej (ale niemożliwej do przeprowadzenia przez państwo radzieckie ze względu na wysokie koszty) melioracji gruntów oraz karczowania lasów w celu powiększenia obszarów uprawnych ${ }^{73}$. Potrzebę pozyskania maszyn do wycinki drzew odczuwało wiele kolonii. Z końcem roku (27 grudnia) dr Rozen przesłał pismo do przewodniczącego Bełkomzet Piszczepowa z informacją o wysłaniu z USA trzech pożądanych maszyn oraz rozrzutek do nawozu ${ }^{74} .17$ kwietnia 1928 r. Biełkomzet przekazał podziękowanie dyrekcji Agro-Jointu za przybyłe do Noworosyjska maszyny ${ }^{75}$. Nowa dostawa kolejnych 10 maszyn do karczowania miała miejsce 3 września tegoż roku ${ }^{76}$.

Oprócz działalności obejmującej wiele kolonii Agro-Joint nierzadko pomagał tylko określonym artelom, które zwracały się do niego $\mathrm{z}$ indywidualną prośbą. $\mathrm{Na}$ początku $1928 \mathrm{r}$. jeden $\mathrm{z}$ arteli w okręgu mochylewskim prosił np., aby organizacja dostarczyła mu rozrzutkę, o którą bezskutecznie od dłuższego czasu zabiega w Bełkomzet-e. Na skutek podjętych działań już 28 maja 1928 r. Biełkomzet zakomunikował Agro-Jointowi, że dostał oczekiwaną maszynę i wysłał ją do adresata ${ }^{77}$.

Należy uzupełnić, iż od 1926 r. Agro-Joint swoją pracę na Białorusi prowadził jednocześnie z działalnością na Krymie. W tymże roku dla osadnictwa m.in. białoruskich Żydów wydzielono 5265 des. odłogów i ugorów, na zagospodarowanie których przeznaczono 6 tys. rubli ${ }^{78}$. Wówczas też na Krymie osiedlono 380 rodzin z guberni homelskiej oraz 321 rodzin żydowskich z pozostałych części Białorusi. Trzeba zauważyć, iż jednocześnie na samej Białorusi umożliwiono zagospodarowanie 402 rodzinom.

W końcu 1929 r. delegacja robotników z Mińska zapoznała się z warunkami życia żydowskich osadników z Białorusi, którzy pracowali w rejonie Eupatorii. W wynikach wizytacji odnotowała ona równie wiele osiągnięć, co uchybień. Podkreśliła jednak ogromne znaczenie działań Agro-Jointu oraz władz i personelu technicznego KOMZET i OZET, bez których ta akcja byłaby niemożliwa ${ }^{79}$.

Wspominając o działalności KOMZET trzeba odnotować, iż w latach 1925-1929 pomagał on 2343 rodzinom. Na przestrzeni tych lat liczebność rodzin objętych jego działalnością kształtowała się następująco: 1925 - 903, 1926 - 400, 1927 - 200,

73 „Zwezda”, 31 V 1927.

74 NARB, f. 11, op. 1, d. 6, 1. 39.

75 Ibidem, f. 11, op. 1, d. 96, 1. 83.

76 Ibidem, f. 11, op. 2, d. 10, 1. 2, 5 .

77 Ibidem, f. 11, op. 1, d. 96, 1. 82.

78 Ibidem, f. 11, op. 1, d. 66, 1. 15 verte. Porozumienie Agro-Jointu, EKO i ORT przewidywało wydzielenie na cele kolonizacji 1375000 rubli. Wydzielono $1 \mathrm{mln}, \mathrm{z}$ czego przeznaczono na potrzeby osadników: na Ukrainie - 454 tys., na Krymie - 6 tys., na Białorusi - 120 tys., dla guberni homelskiej -10 tys., dla północnego Kaukazu - 25 tys., dla OZET na potrzeby centralnego żywienia - 70 tys. i na prace leśne - 315 tys., ibidem, f. 11, op. 1, d. 66a, 1.15 verte.

79 Ibidem, f. 225, op. 2, d. 27, 1. 11-16. 
1928 - 840. W dniu 1 stycznia 1929 r. pod kontrolą Biełkomzet była 1 komuna, 197 arteli i 9 towarzystw, w sumie 207 żydowskich kolektywów posiadających 1613 członków $^{80}$. W drugim i trzecim kwartale tego roku oddano im w użytkowanie 9975 ha ziemi. W poszczególnych okręgach wyglądało to następująco: miński - 3400 ha, homelski - 2250 ha, bobrujski - 2825 ha, mozyrski - 700 ha, mohylewski - 800 ha $^{81}$.

14 czerwca 1930 r. na posiedzeniu KOMZET ZSRR przyjęto uchwałę mówiąca, iż w związku z koncentracją prac umożliwiających osadnictwo rolne ludności żydowskiej na Krymie oraz w Birobidżanie od roku budżetowego 1930-1931 zawiesza się finansowanie działalności kolonizacyjnej na Białorusi ${ }^{82}$. Ta uchwała oznaczała równocześnie koniec aktywnej działalność Agro-Jointu na tych terenach.

Próbując zwięźle podsumować ten sześcioletni okres agraryzacji ludności żydowskiej na Białorusi można stwierdzić, iż gospodarstwa były w pełni rentowne i miały, dzięki pomocy odpowiednich organów państwowych i żydowskich organizacji zagranicznych, dobre perspektywy. Ogółem w latach 1924-1928 oddano do użytku 9526 zagród. Wedle danych z $1928 \mathrm{r}$. na 100 rodzin nowych osadników przypadało 60 domów. Biorąc pod uwagę obszar zasiewów przypadających na każde gospodarstwo żydowskie, to sięgał on 11,6 ha, z czego połowę zajmowały zboża ozime. Według osób oceniających pozytywne rezultaty osadnictwa żydowskiego do rolniczych sukcesów w znacznej mierze przyczyniło się formowanie od samego początku kolektywnych gospodarstw. Organizacje, które finansowały kampanię, przede wszystkim AgroJoint, podkreślały, że łatwiej było w kolektywach tworzyć towarzystwa kredytowe i łożyć na różne kierunki działalności rolnej w celu osiągnięcia wyższej wydajności produkcji. Kolektywne formy gospodarowania pozwoliły żydowskim rolnikom przejść do wielopolówki, wprowadzić progresywne metody intensywnej obróbki pól, wykorzystując pomoc agronomiczną i od początku zakładać swoje gospodarstwa na podstawach towarowych. W pierwszym okresie najbardziej rozpowszechnione były proste formy wspólnot przesiedleńczych np. towarzystwa wspólnej obróbki ziemi. Towarzyszyły im towarzystwa maszynowo-traktorowe, mleczno-towarowe, zapomogowe i kredytowe. Należy zaznaczyć, iż w miarę krzepnięcia gospodarstw zaczął zachodzić proces ich przegrupowywania, a nawet wyodrębniania gospodarstw indywidualnych. Był to niejako naturalny porządek rzeczy, gdyż w pierwszym etapie kolektywy były pospiesznie zakładane, bez liczenia się z czynnikami społecznymi i psychologicznymi, z interesami poszczególnych rodzin, które powinny gwarantować stabilny stosunek do uprawy roli. Niektórzy przesiedleńcy zaczęli patrzeć w przeszłość, na poprzedni styl i warunki życia, inni byli zachwyceni nową rolą społeczną, szukali podobnych sobie i na tej podstawie przegrupowywali się i for-

80 Ibidem, 1. 48.

81 Ibidem, 1. 72.

82 Ważkie zagadnienie udziału Agro-Jointu w osadnictwie na Krymie i w Birobidżanie, wykraczając poza ramy artykułu, wymaga odrębnego opracowania. Literatura przedmiotu jest bardzo bogata, patrz np.: M. Kalinin, Ob. Obrazovaniji Jevriejskoj avtonomnoj obłastii, Moskva 1935; M. Lepecki, Birobidźan Żydowski Obwód Autonomiczny w ZSRR, Warszawa 1937; V. Kostikov, The People and Land Borobidzhan, Moskow 1979; A. Patek, Birobidżan Sowiecka ziemia obiecana?, Kraków 1997. 
mowali nowe kolektywy. Te przegrupowane gospodarstwa charakteryzowały się wysokim poziomem inicjatywy, staranności i kultury rolnej.

$\mathrm{Z}$ początkiem lat 30. zaczęto wszystkich rolników grupować w kołchozy. Większość kolonistów odnosiła się do tych poczynań krytycznie. Do końca 1931 r., pod silnym naciskiem Ewsiekcji i KOMZETu zdołano skołchozować aż 95\% gospodarstw. W porównaniu z innymi narodowościami był to wskaźnik najwyższy. Przyczyn tak szybkiego przejścia do gospodarki kołchozowej ludności żydowskiej było kilka. Przeważyła jednak wizja głodu będąca rezultatem nieurodzaju. Dotknął on zwłaszcza nowych przesiedleńców ulokowanych na gorszych ziemiach, pozostałych po obdzieleniu miejscowych gospodarzy, którzy pozyskali lepsze przydziały. Połączenie rolników w kołchozy miało złagodzić kłopoty z żywnością. Zewsząd płynęły doniesienia o braku zapasów ${ }^{83}$. Na ich podstawie Kierownik Ewsiekcji CK KP(b) sporządził do władz wyższych alarmującą notatkę: „....na żydowskich przesiedleńczych fondach stworzyło się w większym stopniu ciężkie położenie. Ludzie w sensie dosłownym głodują. Znaczna część rodzin już od tygodni żywi się namiastkami. Całej ludności żydowskiej grozi katastrofa" ${ }^{84}$.

Po przeprowadzeniu masowej kolektywizacji władze zamiast pomóc kołchozom okrzepnąć, „stanąć na nogi”, zastosowały politykę dalszego czerpania zysków, politykę grabieży. Kołchozy zobowiązane były płacić wysokie podatki i wypełniać rosnące z każdym rokiem plany dostaw zbóż. Jeśli w 1929 r. kołchoźnicy zobowiązani byli dostarczyć 4,74 centnary z hektara, to dwa lata później już 6 centnarów. Należy przy tym zaznaczyć, że plany dostaw zbóż nie uwzględniały nieurodzajów i wiele gospodarstw nie było w stanie ich wypełnić.

W latach 1932-1933 normy wzrosły tak bardzo, że w wielu kołchozach nie było ziarna na pokrycie własnych potrzeb. Nie bacząc na taką dramatyczną sytuację przedstawiciele KOMZETu i władz miejscowych chodzili po domach i zabierali resztki. W żydowskich gospodarstwach nastał głód.

Nie licząc się z ludźmi, a dbając jedynie o zaspokojenie potrzeb państwa, na posiedzeniach rejonowych komitetów (raispołkomow) sformułowano jednakowo brzmiące, zrytualizowane wnioski. Na przykład 17 września 1932 r. analizując „przebieg żniw i wypełnienie planu dostaw żniwnych” odnotowano: „,kołchozy znacznie naruszyły dyrektywy partii i rządu, aby zmniejszyć straty, nie mobilizują wszystkich sił i możliwości zbioru zbóż”. Wniosek końcowy był jednoznaczny: „Przekazać odpowiednim władzom sprawę arteli i pociągnąć do odpowiedzialności zarząd za dopuszczenie do skandalicznych strat w zbiorach..." ${ }^{85}$. Ich działania zostały ocenione jako umyślne zatrzymanie wypełnienia planu dostaw zbożowych. Chcąc podwyższyć dalekie od planowanych dostawy zbóż, władze zabierały całość plonów i jednocześnie zakazywały wydawania jakichkolwiek zaliczek w naturze wszystkim kołchozom, które nie wypełniły planów rocznych. Komitety wiejskie (Sielsowiety)

83 Archiv CK KPU, f. 1, op. 20, d. 2689, 1. 11-12.

84 Ibidem, l. 17.

85 CGAOR, f. 1, op. 8, d. 311, 1. 319-329. 
zobligowano do zorganizowania dodatkowego zbioru u poszczególnych kołchoźników i we wskazanych gospodarstwach. W pierwszej kolejności konfiskatę nakazano przeprowadzić u „próżniaków, zdzierców i zdeklasowanego elementu”, który miał przepracowaną małą liczbę dni pracy. Zarządzono umieszczenie kołchozów na czarnej liście z konfiskatą wszystkich artykułów przemysłowych i zaprzestaniem dalszego dostarczania towarów. Uprzedzono, że jeśli w najbliższych dniach nie będzie zdecydowanego przełomu w wypełnieniu planu, to zapadnie decyzja o zamianie dostaw zbóż na rzecz wypełnienia planu dostaw mięsa. Kierowników kołchozów polecono oddać pod sąd za sabotaż dostaw ${ }^{86}$.

Choć następstwa masowej grabieży były tragiczne, tylko w pewnej mierze znalazły one odbicie w prasie tego okresu. W marcu pisano, iż w wielu kołchozach „plany dostaw za ubiegłe dwa lata do tego czasu są niewypełnione, a gospodarstwa te nie są przygotowane do siewu..." ${ }^{\prime 7}$. Mimo wielkiej tajności, o głodzie w żydowskich miasteczkach i kołchozach, pozbawionych centralnego zaopatrzenia w żywność, wiedziano w wielu krajach. Pisały o nim m.in. gazety Polski i USA. Przedstawiciele żydowskich organizacji z Polski, Stanów Zjednoczonych, Francji i Anglii starali się pomóc głodującym i zwracali się do władz z prośbami o zgodę na ich przyjazd. Za każdym razem jednak przedstawiciele partii i rządu zapewniali, że żadnego głodu nie ma i zezwolenia na wjazd nie udzielano.

W okresie Wielkiej Czystki pion kierowniczy Agro-Jointu stał się celem prześladowań organów sowieckich. Wielu agronomów, zootechników, hodowców, wykwalifikowanych przewodniczących kołchozów represjonowano, zsyłając do więzień i obozów lub skazano na karę śmierci, jako agentów obcych wywiadów. W kolejnych latach po działaczach Jointu prawie wszyscy aktywiści KOMZETu byli represjonowani. Obwiniono ich o nieumiejętne pokierowanie kolektywami przesiedleńców żydowskich, sabotaż i wrogą działalność. Historii gospodarstw żydowskich na Białorusi dopełniła II wojna światowa. Przestały wówczas istnieć nawet te nieliczne, które przetrwały lata głodu.

Kres istnienia gospodarstw żydowskich oznaczał jednocześnie fiasko radzieckiej polityki narodowościowej zmierzającej m.in. do zespolenia poszczególnych społeczności (w tym żydowskiej) i przyjęcia przez nie jednego, wspólnego, radzieckiego systemu wartości, norm i ocen. Polityka integracyjna państwa radzieckiego, aktywnie wspierana przez organizacje zagraniczne, nie zdołała też „wydobyć” ludności żydowskiej z zajmowanego przez nią szczególnego miejsca w społeczeństwie. Swoistość jej położenia wynikała m.in. z uczestnictwa we władzy wielu działaczy żydowskich i prawie $3 \mathrm{mln}$ Żydów żyjących w ich złowieszczym cieniu, otoczonych niechęcią i podejrzliwością wielu mieszkańców ZSRR. Należy jednak podkreślić, iż mimo oskarżenia Agro-Jointu o wrogą działalność i wieloletniej zmowy milczenia na temat jego zasług, działalność tej organizacji przyczyniła się do uratowania wielu tysięcy istnień. Pomoc zagraniczna pomogła wielu Żydom odczuć przynależ-

86 Ibidem, 1. 305-306.

87 „Der Sztern”, 12 III 1932. 


\section{ność do narodu żyjącego w diasporze i nierzadko stanowiła o zachowaniu kultury żydowskiej i tożsamości narodowej ${ }^{88}$.}

\section{Joint and Agro-Joint support to the Jewish community in Soviet Belarus}

The presence of the Jewish population in the Russian countryside goes back to the beginning of the 19th century. Attempts of resolving the "Jewish problem", which appeared in consequence of the annexation of Polish territories, were already made in the tsarist times through the resettlement of thousands of Jews into rural areas. By working the soil, the Jews started to belie the many stereotypes associated with their activities and sources of income, and entered the 20th century with vast experience in agriculture.

The Soviet state that emerged after 1917 became the heir of the Russian Empire and a geopolitical situation altered by the revolution and its emancipation movements, which the Bolsheviks intended to preserve and consolidate in order for different communities to adopt one common Soviet system of values, norms and opinions.

Among the nations embraced by the ethnic integration policies, the Jewish community was considered an individual case, as the Soviet notion of "nation" did not apply to them, nor could they be ascribed to either of the social classes. The social structure of the Jewish community, distinctive by its high proportion of small merchants and artisans, clearly differed from the Soviet model of a state of workers and peasants. Another specific aspect was the presence of numerous Jewish activists in the authorities, with the 5 million Jews living in their ominous shadow.

The resettlement of the Jewish community into rural areas was one of the aspects of the ethnic integration policies. The operation, launched by the Central Committee of the RCP(b) in 1924 , aimed to facilitate the formation of a peasant stratum in the Jewish society, which would transform its culture in a way to merge the Jews with the multinational population of the USSR.

Considering the lack of state funds, the implementation of the top-down plan was made possible by financial aid from external sources, the American organisation Agro-Joint in particular, which covered most of the costs related to providing the settlers with tractors and farm equipment, building wells and houses, and financing credit unions to support various types of

88 Zakończenie oficjalnej działalności Agro-Jointu na Białorusi nie oznaczało całkowitego wycofania się z pomocy Żydom na obszarze ZSRR. Popłynęła ona szerokim strumieniem zwłaszcza w czasie II wojny światowej. W 1942 r. Joint wespół z Agencją Żydowską i Światowym Żydowskim Kongresem współpracował z polskim rządem na emigracji. W ramach tej współpracy uczestniczył w organizowaniu pomocy dla bieżeńców (uciekinierów z Polski, w znacznej części żydowskiej narodowości, którzy, uciekając przed najazdem faszystowskich Niemiec, znaleźli się w ZSRR). Pomoc obejmowała dostarczanie do adresatów (o miejscach pobytu których wiedziano) paczek zawierających środki medyczne, żywność i odzież. O skali pomocy najlepiej świadczy jej wymierna ilość - do połowy 1943 r. Joint wraz z innymi żydowskimi organizacjami przesłał do Związku Radzieckiego 100 tys. paczek o łącznej wadze 252,2 ton. Z czasem władze radzieckie zaczęły podkreślać, iż indywidualna pomoc oraz znajdujące się w przesyłkach rzeczy, nie zawsze pierwszej potrzeby, mogą wywołać niezadowolenie innych narodowości ZSRR pozbawionych takiej pomocy i dążyły do jej ograniczenia. Wagi doręczanej pomocy nie da się przecenić. Nawet wzmiankowane przez władze artykuły „nie pierwszej potrzeby” można było wymienić i uzyskać w ten sposób np. ziemniaki lub zboże, co stanowiło o przeżyciu. Należy dodać, iż kierownictwo Jointu, nie chcąc dopuścić do jakiejkolwiek dyskryminacji, próbowało porozumieć się bezpośrednio z przedstawicielami ZSRR w USA. Deklarowało nawet pomoc ekonomiczną dla kraju, z której tylko część miałaby służyć polepszeniu bytu narodu żydowskiego. Chciano np. wskrzesić osiedla na Krymie, przeznaczając na ten cel 500 tys. dolarów. Zob.: Sovetskie ljudi piszut Ile Epenbyrgu. 1943-1966, Jerusalim 1993, s. 222-223. 
agricultural activity. In total, the organisation provided an average funding amount of 2 million roubles per year.

As they owned modern farm equipment, otherwise rare in the Russian countryside, the Jews were able to help farmers of other ethnicities, thus opposing the existing anti-Semitic sentiments, and proving that the division into good and bad is not limited to ethnic differences. The inspections conducted in the new settlements allowed to conclude that the Jewish community succeeded at intensifying its farming methods and even gradually paying back its loans. The acknowledgment of its successes, its determination in overcoming difficult living conditions, and its ability to cooperate and coexist with the other nations of the USSR, allows us to present the evolution of the perception of Jews in a wider social, cultural and political context. It also proves the role of financial and material support offered by Agro-Joint in the success of this side of the ethnic integration policies of the Soviet Union.

Translated by Jakub Perliński

\section{Помощь Джойнт и Агро-Джойнт еврейскому населению на территории советской Белоруссии.}

Сельскохозяйственное заселение еврейским населением на территории России имеет долгую историю, датирующуюся началом XIX века. Уже в царские времена «еврейскую проблему», возникшую вследствие присоединения польских земель, пытались разрешить м пр. разрешив обработку земли многим тысячам людей этой национальности. Евреи занимавшиеся земледелием постепенно стали опровергать многие стереотипы, связанные н пр. с их деятельностью и источниками содержания и вошли в двадцатый век с опытом в ведении хозяйства.

Образовавшееся после 1927г. советское государство стало преемником царской империи, геополитическое пространство которой, взорванное революцией и возбужденное ее эмансипационными движениями, большевики намеревались удержать. Сплотить таким образом, чтобы отдельные общины приняли одну, общую, советскую систему ценностей, норм и оценок.

Среди наций, на которые распространилась интеграционная национальная политика, особенное место заняло еврейское население. К нему нельзя было ни применить советское определение нации, ни подчинить его ни одному из классов. Социальная структура евреев, отличавшаяся участием значительной доли мелких торговцев и ремесленников, заметно не соответствовала советской модели государства рабочих и крестьян. Особенность его положения являлась также результатом участия во власти многих еврейских деятелей и почти 5 миллионов евреев, которые жили в их зловещей тени.

Фрагментом интеграционной национальной политики являлась аграрная кампания по переселению. Постановленная Центральным Комитетом РКП(б) в 1924г., колонизационная кампания должна была способствовать формированию в еврейском обществе крестьянского слоя (аграгизации), а значит трансформировать его культуру в направлении к соединению с многонациональным советским обществом.

В связи с нехваткой государственных денежных средств, исполнение планов, установленных «сверху», стало возможным благодаря финансовой поддержке из вне, особенно от американской организации Агро-Джойнт. Именно она взяла на себя большинство расходов по снабжению новых поселенцев в тракторы и сельскохозяйственную технику, строительство колодцев, а также домов, а также дала средства на деятельность кредитных обществ, финансирующих различные направления аграрной деятельности. Средняя помощь колонистам от этой организации была в размере 2 миллионов рублей в год. 
Евреи, имея в своем распоряжении современную сельскохозяйственную технику, которая редко встречалась в русских деревнях, помогая крестьянам других национальностей, своим поведением опровергали антисемитские взгляды, доказывали, что деление на хороших и плохих, идет не только в этнической плоскости. Благодаря проведенным инспекциям новых поселений можно было заключить, что еврейское население интенсифицировало сельское хозяйство и даже постепенно гасило кредиты. Презентация этих достижений, как и решительности в преодолении сложных бытовых условий, умения взаимодействовать и сожительствовать с другими нациями СССР, сделало возможным представить эволюцию в восприятии еврейского населения в широком общественном, культурном и политическом контексте. Автор показывает роль финансовой и материальной помощи организации Агро-Джойнт, которую она сыграла в успехе этой части интеграционной национальной политики советского государства.

Перевод Агнешка Поспишыль

\section{Bibliografia}

Chenkin E. M., Oczerki istorii borby sovietskogo gosudarstva s gołodom (1921-1922 gg), Krasnojarsk 1988.

Chenkin E. M., O roli „Dżonta” w okazanii pomoszczi Rossii i Ukraine v 1921-23 rr., „Vestnik Evrejskogo universiteta w Moskve", no. 4, 1993.

Edmondson Ch. M., An Inquiry into the Termination of Soviet Famine Relief Programmes and the Renewal of Grain Export, 1922-23, „Soviet Studies”, Vol. 33, No. 3 (1981).

Fisher H., The Famine in Soviet Russia: 1921-1923. The Operations of the American Relief Administration, New York, Macmilan, 1927.

Gierowska-Kałłaur J., Polacy i Białorusini we wzajemnych opiniach w latach 1918-1921, „Studia z Dziejów Rosji i Europy Środkowo-Wschodniej”, 42, 2007.

Straż Kresowa wobec kwestii białoruskiej. Deklaracje i praktyka, „Studia z Dziejów Rosji i Europy Środkowo-Wschodniej", 44, 2009.

Aktywność środowisk polskich w Mińszczyźnie w realiach lat 1919-1920, „Studia z Dziejów Rosji i Europy Środkowo-Wschodniej", 45, 2010.

Golde J. W., Zemelnoe ustrojstwo trudjaszczichsja evreev, Moskva 1925.

Gurevicz M. B., Gołod i selskoe chozjajstvo Ukrainy, Charkov 1923.

Ivnickij N. A., Repressivnaja polityka sovietskoj vłasti v derevne (1928-1933), Moskva 2000.

Joffe E., Mielcer B., Dżoint v Biełorusi, Minsk 1999.

Kalinin M., Ob. Obrazovaniji Jevriejskoj avtonomnoj obłastii, Moskva 1935.

Kostikov V., The People and Land Borobidzhan, Moskow 1979.

Lepecki M., Birobidżan Żydowski Obwód Autonomiczny w ZSRR, Warszawa 1937.

Micel M., Posleniaja głava. Agro-Dżojnt v gody Bolszogo tierrora, Kiiv 2012.

Patek A., Birobidżan Sowiecka ziemia obiecana?, Kraków 1997.

Privałova T. V., Byt rossijskoj derevni 60-e gody XIX-20-e gody XX w., Moskva 2000.

Sbornik statej po evriejskoj istorii i literaturze, t. 2, cz. 1, Israel 1992.

Serbin R., Gołod 1921-1923 i ukrainska presa v Kanadi, Toronto 1992.

Ewa Kowalska-Dąbrowska - doktor nauk humanistycznych w zakresie historii Instytutu Historii im. Tadeusza Manteuffla PAN, pracownik Muzeum Katyńskiego w Warszawie. 